\title{
Study of the interaction between self-assembling peptide and mangiferin and in vitro release of mangiferin from in situ hydrogel
}

This article was published in the following Dove Press journal: International Journal of Nanomedicine

\author{
Cui Meng ${ }^{1-3, *}$ \\ Weipeng Wei ${ }^{1,2, *}$ \\ Yuhe Wang ${ }^{1,3}$ \\ Kunqin Zhang ${ }^{1,2}$ \\ Ting Zhang ${ }^{1,2}$ \\ Yunyan Tang ${ }^{1,2}$ \\ Fushan Tang ${ }^{1,2}$
}

'Department of Clinical Pharmacy, School of Pharmacy, Zunyi Medical University, Zunyi 563006, People's Republic of China; ${ }^{2}$ The Key Laboratory of Clinical Pharmacy in Zunyi City, Zunyi 563006, People's Republic of China; ${ }^{3}$ Department of Pharmacy, The First Hospital Affiliated to Zunyi Medical University, Zunyi 563003, People's Republic of China

*These authors contributed equally to this work
Correspondence: Fushan Tang School of Pharmacy, Zunyi Medical University, Zunyi 563006, People's

Republic of China

Tel +8685I28642337

Email fstang@vip.163.com
Objective: This study aimed to investigate the interaction between the ion-complementary self-assembling peptide RADA16-I and the hydrophobic drug mangiferin (MA), and the potential of the self-assembling peptide to be exploited as a drug carrier of MA.

Methods: The RADA16-I-MA suspension was prepared by magnetic stirring, followed by fluorescence spectrophotometry, particle size determination, rheological properties analysis, and in vitro release assay to characterize the interaction between RADA16-I and MA. Then, the effects of in situ MA-loaded hydrogel on the proliferation of KYSE 30 and DLD-1 tumor cells and the toxic effect of the hydrogel on $293 \mathrm{~T}$ renal epithelial cells were studied by the Cell Counting Kit 8 method.

Results: The RADA16-I-MA suspension was formed in water under magnetic stirring; the in situ hydrogel was formed when the suspension was added to PBS. The particle size in the RADA16-I-MA suspension was around 300-600 nm with an average size of $492 \mathrm{~nm}$. Within $24 \mathrm{~h}$, the cumulative release of MA from the RADA16-I-MA hydrogel was about $80 \%$. The release rate of MA from the hydrogel was dependent on the concentration of RADA16-I and the release can be fitted with a first-order kinetic equation. The results suggested that the selfassembling peptide can stabilize MA in water to form a relatively stable suspension; the results also indicated that controlled release of MA from the RADA16-I-MA in situ hydrogel formed from the RADA16-I-MA suspension can be achieved by adjusting the concentration of the peptide in suspension. The cell viability studies showed that the RADA16-I-MA in situ hydrogel not only can maintain or enhance the intrinsic proliferation inhibition effects of MA on tumor cells, but also can reduce the toxicity of MA to normal cells.

Conclusion: The self-assembling peptide RADA16-I can be a potential candidate for constructing a delivery system of the hydrophobic drug MA.

Keywords: RADA16-I, hydrophobic drug, delivery system, antitumor

\section{Introduction}

Many drug candidates have poor water solubility, which leads to less useful activity in clinical applications and also limits the development of their new formulations. Although there are many studies using novel derivatives or prodrugs to increase the water solubility of certain drugs and then increase their bioavailability, exploiting new drug carriers to transport hydrophobic drugs is still the main research and development route. ${ }^{1,2}$

Since the late $1980 \mathrm{~s}$, short peptides extracted from natural proteins with selfassembling properties have begun to attract more and more research interest. ${ }^{3}$ The 
self-assembling peptides have been widely investigated in many fields including material science, tissue engineering, and drug delivery. ${ }^{4-6}$ The self-assembling peptides usually include ion-complementary self-assembling peptides, amphiphilic peptides, cyclic peptides, surface-active peptides, aromatic peptides, and many others. ${ }^{7}$ The ion-complementary self-assembling peptides are composed of positively charged amino acids, negatively charged amino acids, and hydrophobic amino acids. They have a structure in which a positively charged amino acid and a negatively charged amino acid are alternately arranged with a hydrophobic amino acid and thus can self-assemble under the electrostatic force, hydrophobic interaction, and hydrogen bonding between the amino acids. ${ }^{8}$ As a representative of ion-complementary self-assembling peptides, RADA16-I is structurally composed of positively charged arginines (Arg, R), negatively charged aspartic acids (Asp, D), and hydrophobic amino acid alanine (Ala, A) with complementary ionic side modulus $\mathrm{I},+-+-+-+-$. It has been commercialized and widely investigated in the biomedical field, ${ }^{9-11}$ such as cell culture, tissue engineering, and drug delivery. ${ }^{12,13}$ This kind of peptide is able to form a $\beta$-sheet secondary structure, a nanofiber structure by self-assembling, and then a hydrogel. ${ }^{14-16}$ Self-assembling peptides may become good carriers for hydrophobic drugs because the hydrophobic side in their secondary structure can interact with hydrophobic drugs and the hydrophilic side can stabilize the particles in aqueous solutions. ${ }^{17,18}$ It was found that the self-assembling peptide was able to carry the hydrophobic compound pyrene as a carrier for drug delivery and stabilize pyrene microcrystals in aqueous solution. Pyrene can be released from the suspension of peptide-pyrene to enter egg phosphatidylcholine vesicles. ${ }^{19-21}$

Hydrogels are one of the most researched sustainedrelease drug delivery systems in recent years. They have a hydrophilic three-dimensional network structure and a strong water absorption capacity of $10 \%$ to thousands of times its actual dry weight. Hydrogels have many properties, including good biocompatibility, high water content, and good viscoelasticity, which play a major role in regenerative medicine and drug delivery. ${ }^{22-25}$ In situ hydrogel is a process in which a drug is administered in the form of a solution or suspension and undergoes a phase transition immediately under the trigger of certain conditions, and finally forms a nonchemically crosslinked semisolid preparation at the administered site. ${ }^{23,26,27}$ Since in situ hydrogels can achieve a unique mode of administration from solution or suspension to hydrogels, they have been widely used for the development of new dosage forms in recent decades.

Mangiferin (MA) is a poorly water-soluble polyphenolhydroxyl diphenyl and pyranoid ketone carbon glycoside, with a solubility reported as $0.111 \mathrm{mg} / \mathrm{mL}$ in water. ${ }^{28}$ Modern pharmacological studies have shown that MA has a variety of pharmacological effects, such as anti-inflammatory effects, ${ }^{29}$ antioxidation, ${ }^{30,31}$ immune regulation, ${ }^{1,20}$ and other effects. ${ }^{32,33}$ However, its poor solubility in water limits the development of its preparation, and severely affects the bioavailability of its solid formulations. ${ }^{34-36}$

In this paper, we report the interaction between the selfassembling peptide RADA16-I and MA and the potential of the self-assembling peptide as a drug delivery carrier to encapsulate and release MA for the first time. This will enhance understanding of the interaction between self-assembling peptides and hydrophobic drugs. The research will be helpful for further exploitation of self-assembling peptides as practical and effective carriers for hydrophobic drugs.

\section{Materials and methods}

\section{Materials}

Self-assembling peptide RADA16-I (Ac-RADARADA RADARADA-CONH $2,1712.78 \mathrm{~g} / \mathrm{mol}$, purity $>98 \%$ ) was synthesized by Shanghai Biotech BioScience \& Technology (Shanghai, People's Republic of China). The $\mathrm{N}$-terminus and C-terminus of the peptide were protected by acetyl and amino groups, respectively. Synthesized product was stored at $-20{ }^{\circ} \mathrm{C}$, and used without further purification. MA (99\% purity) was purchased from Guizhou Dida Biological Technology Co, Ltd. (Guiyang, Guizhou Province, People's Republic of China). All other reagents and chemicals were of analytical grade and used directly. Double-distilled water was used in all experiments. Human cancer cell lines KYSE 30 (human esophageal cell line) and DLD-1 (human colorectal cell line) and the human normal renal epithelial cell line 293T were all kindly donated by the State Key Laboratory of Molecular Oncology, Cancer Hospital, Chinese Academy of Medical Sciences, Peking Union Medical College. Cell culture bottles and other related consumables were purchased from Corning Incoroprated (Corning, NY, USA).

\section{Preparation of peptide solution}

RADA16-I stock solution $(10 \mathrm{mg} / \mathrm{mL})$ was prepared by dissolving lyophilized peptide powder in pure water, followed 
by an ultrasonic sonication for $10 \mathrm{~min}$, and was stored at $4{ }^{\circ} \mathrm{C}$ for $48 \mathrm{~h}$ and diluted as needed with pure water before use.

\section{Fluorescence spectroscopy}

The interaction between self-assembling peptide and MA was measured by fluorescence spectrophotometer (F-380; Guangdong Technology Development Co. Ltd, Tianjin, People's Republic of China).

Preparation of the peptide-MA solutions and the fluorescence study

The RADA16-I-MA solutions for fluorescence investigation were prepared as follows: MA powder was dissolved in methanol to obtain the stock solution $(1 \mathrm{mg} / \mathrm{mL})$. Then, $250 \mu \mathrm{L}$ of MA-methanol solution was transferred into a glass vial and placed in the fume hood to form a light-yellow thin film of MA at the bottom of the vial. The RADA16-I solutions with different concentrations of $10-100 \mu \mathrm{g} / \mathrm{mL}$ were added to the glass vial, respectively, followed by sonication for $3 \mathrm{~h}$, and allowed to equilibrate at room temperature in the dark for sufficient time (usually $24 \mathrm{~h}$ ). The final concentration of MA was 30-50 $\mu \mathrm{g} / \mathrm{mL}$. MA in pure water solution was used as the control.

To study the fluorescence spectra of MA in a series of concentrations of peptide solution, $3 \mathrm{~mL}$ of each sample was put into a quartz cuvette. The sample was excited at $277 \mathrm{~nm}$ and the emission spectra were collected from 400 to $600 \mathrm{~nm}$. The excitation and emission slit widths were both set as $10 \mathrm{~nm}$, the PMT (photomultiplier tube) voltage was $600 \mathrm{~V}$, the scan speed was $1200 \mathrm{~nm} / \mathrm{min}$, and the response time was $0.05 \mathrm{~s}$. All samples in the cuvette were scanned through the right angle optical path measurement at room temperature.

Preparation of the peptide-MA suspension and the fluorescence study

$0.5 \mathrm{mg} / \mathrm{mL}$ RADA16-I aqueous solution was added to MA films similarly prepared as already mentioned, and the emission spectra and fluorescence intensity at $560 \mathrm{~nm}$ of MA in the suspension were recorded immediately after the suspension was magnetically stirred for $0.5,2,4,8,12,24,48$, and $72 \mathrm{~h}$. The final concentration of MA was $0.2 \mathrm{mg} / \mathrm{mL}$. The fluorescence spectroscopy was carried out similarly to that on solutions.

\section{Maximum suspension concentration of MA in the peptide-MA suspension}

To prepare the RADA16-I-MA suspension, RADA16-I water solutions at peptide concentrations of $0.01,0.1$, and $0.2 \mathrm{mg} / \mathrm{mL}$ were added to MA films similarly prepared as already mentioned, respectively, followed by magnetic stirring for $48 \mathrm{~h}$. The proper amount of suspension was diluted and dissolved with methanol 50 times. The absorbance of MA in the diluted solutions at $240 \mathrm{~nm}$ was determined by UV spectrophotometer. MA reference was dissolved in a solution containing 2\% water and $98 \%$ methanol, and then diluted to a series of expected concentrations. The standard linear equation was obtained by linearly fitting the absorbance to the MA concentration (4-18 $\mu \mathrm{g} / \mathrm{mL}$ ). The maximum amount of MA suspended in the suspension was calculated by the standard curve and compared to the given original MA concentration (about $0.3 \mathrm{mg} / \mathrm{mL}$ ).

\section{Particle size distribution of the RADA 16- I-MA suspension}

The particle size distribution of the RADA16-I-MA colloidal suspensions was determined by the laser particle size analyzer (Brookhaven Instruments, Holtsville, NY, USA), and the test temperature was maintained at $25{ }^{\circ} \mathrm{C}$. Colloidal suspensions with RADA16-I at concentrations of $0.01,0.1$, and $1 \mathrm{mg} / \mathrm{mL}$ and MA with a concentration of $0.5 \mathrm{mg} / \mathrm{mL}$ were prepared according to method similar to that described in part "Maximum suspension concentration of MA in the peptide-MA suspension". Each sample was assayed three times and the particle size expressed as mean \pm SD

\section{Formation of RADA I6-I-MA in situ hydrogel and rheological analysis of in situ hydrogel}

The in situ hydrogel was prepared by quickly adding $100 \mu \mathrm{L}$ RADA16-I-MA colloidal suspension to PBS (pH 7.4) and allowed to stand for 10 min to observe the gel state.

The dynamic rheological characterization of the RADA16-MA suspension and hydrogel was performed on a DHR-1 rheometer (TA Instruments, New Castle, DE, USA).RADA16-I-MA suspension was transferred to the rheometer plate, and the parallel plate was then lowered to a gap of $250 \mu \mathrm{m}$. For the RADA16-I-MA hydrogel, RADA16-I-MA suspensions were mixed with PBS quickly at a volume ratio of $1: 1$ and then placed on a rheometer plate. After equilibration for $5 \mathrm{~min}$, the parallel plate was then lowered to a gap of $250 \mu \mathrm{m}$. Subsequently, G' and G" were measured following the procedure already described. 


\section{In vitro drug release}

To obtain drug-loaded hydrogels with different concentrations of RADA16-I, colloidal suspensions containing RADA16-I at concentrations of 5 and $10 \mathrm{mg} / \mathrm{mL}$ were prepared according to method similar to that described in part "Maximum suspension concentration of MA in the peptide-MA suspension".

The release of MA from RADA16-I-MA hydrogel was investigated in PBS solution containing $0.3 \%$ of sodium dodecyl sulfate (SDS). The accumulative release of MA was determined by dialysis through a membrane with molecular weight cutoff larger than $3500 \mathrm{Da}$. An aliquot of $200 \mu \mathrm{L}$ colloidal suspension was dripped to the dialysis bag with $1 \mathrm{~mL}$ PBS, allowed to stand for $10 \mathrm{~min}$, and then each dialysis bag was immersed into $20 \mathrm{~mL}$ of release media and incubated at $37{ }^{\circ} \mathrm{C}$ with shaking at $100 \mathrm{rpm}$ after the extra PBS was removed gently. At $0.25,0.5,1,2$, $4,6,8,12,24,36$, and $48 \mathrm{~h}, 2 \mathrm{~mL}$ of release medium was taken out and replaced with $2 \mathrm{~mL}$ of fresh release media. The release media satisfied the sink conditions, and the experiments were performed in triplicate and the average value was calculated. Each sample was filtered through a $0.45-\mu \mathrm{m}$ microporous membrane and measured at $240 \mathrm{~nm}$ on the UV spectrophotometer (Beijing Purkinje General Instrument Co., Ltd, Beijing, People's Republic of China). The calibration curves were obtained by gradually diluting MA stock solutions in release media and absorbance measured at $240 \mathrm{~nm}$.

\section{In vitro cell viability studies}

KYSE 30, DLD-1, and 293T cells were cultured in a 96well plate at a density of $1.25 \times 10^{4}$ RADA16-I-MA hydrogels $(30,60,90,120,150,180,210$, and $240 \mu \mathrm{M})$ and incubated for 24,48 , and $72 \mathrm{~h}$ at $37{ }^{\circ} \mathrm{C}$. Untreated cells incubated in medium and the medium served as control and blank, respectively. After incubation, Cell Counting Kit $8(10 \mu \mathrm{L} /$ well $)$ was added into each well. Cells were further incubated with Cell Counting Kit 8 for 4 h. Cell viability was assessed by measuring absorbance at $450 \mathrm{~nm}$ using a 96-plate reader (Bio-A-MA hydrogels (30, 60, 90, $120,150,180,210$, and $240 \mu \mathrm{M})$ and incubated for 24,48 , and $72 \mathrm{~h}$ at $37^{\circ} \mathrm{C}$. Untreated cells incubated in medium and the medium served as control and blank, respectively. After incubation, Cell Counting Kit $8(10 \mu \mathrm{L} /$ well $)$ was added into each well. Cells were further incubated with Cell Counting Kit 8 for 4 h. Cell viability was assessed by measuring absorbance at $450 \mathrm{~nm}$ using a 96-plate reader (Bio-Rad Laboratories, Inc., Hercules, CA, USA).

\section{Statistical analysis}

All data were presented as mean $\pm \mathrm{SD}$, and statistical analysis was conducted using Graph Pad Prism 7. Student's $t$-test or one-way ANOVA was used to compare the difference between groups, and a value of $p<0.05$ was defined as statistically significant.

\section{Results and discussions}

\section{Interaction between RADAI6-I and MA}

Formation of a colloidal suspension of RADA I6-I and MA

In pure water, MA showed very low solubility of about $2.6 \times 10^{-4} \mathrm{M}^{28}$ The MA suspension in pure water remained a light-yellow color even after mechanically stirring for $48 \mathrm{~h}$. MA powders were floated in the water or attached to the vial wall during stirring; a few minutes after stopping stirring, MA powders sunk to the bottom of the vial. When the MA powder was stirred in RADA16-I water solution, a milky colloidal suspension was gradually formed. The turbidity of the colloidal suspension related to the concentration of RADA16-I. When the concentration of RADA16-I was very low $(0.01 \mathrm{mg} / \mathrm{mL})$, parts of the MA became a suspension and the rest stuck to the vial wall or floated on the surface of the liquid. When the concentration of RADA16-I increased to $1 \mathrm{mg} / \mathrm{mL}$, the MA was almost completely suspended in the solution (Figure 1).

\section{Fluorescence study on the interaction between RADAI6-I and MA}

Figure 2A shows the fluorescence emission spectra of MA $(50 \mu \mathrm{g} / \mathrm{mL}$, a concentration lower than the saturated solubility of MA in water) in aqueous solutions with the self-assembling peptide RADA16-I at a series of concentrations of $0-0.08 \mathrm{mg} / \mathrm{mL}$. When the excitation wavelength was set at $277 \mathrm{~nm}$, the maximum emission fluorescence intensity of MA at $560 \mathrm{~nm}$ increased significantly with increasing concentration of RADA16-I, showing a peptide concentration dependence. This phenomenon may be attributed to the interaction between MA and the self-assembling peptide RADA16-I. The increase of MA fluorescence intensity with the increase of RADA16-I concentration may reflect incorporation of MA into the hydrophobic 


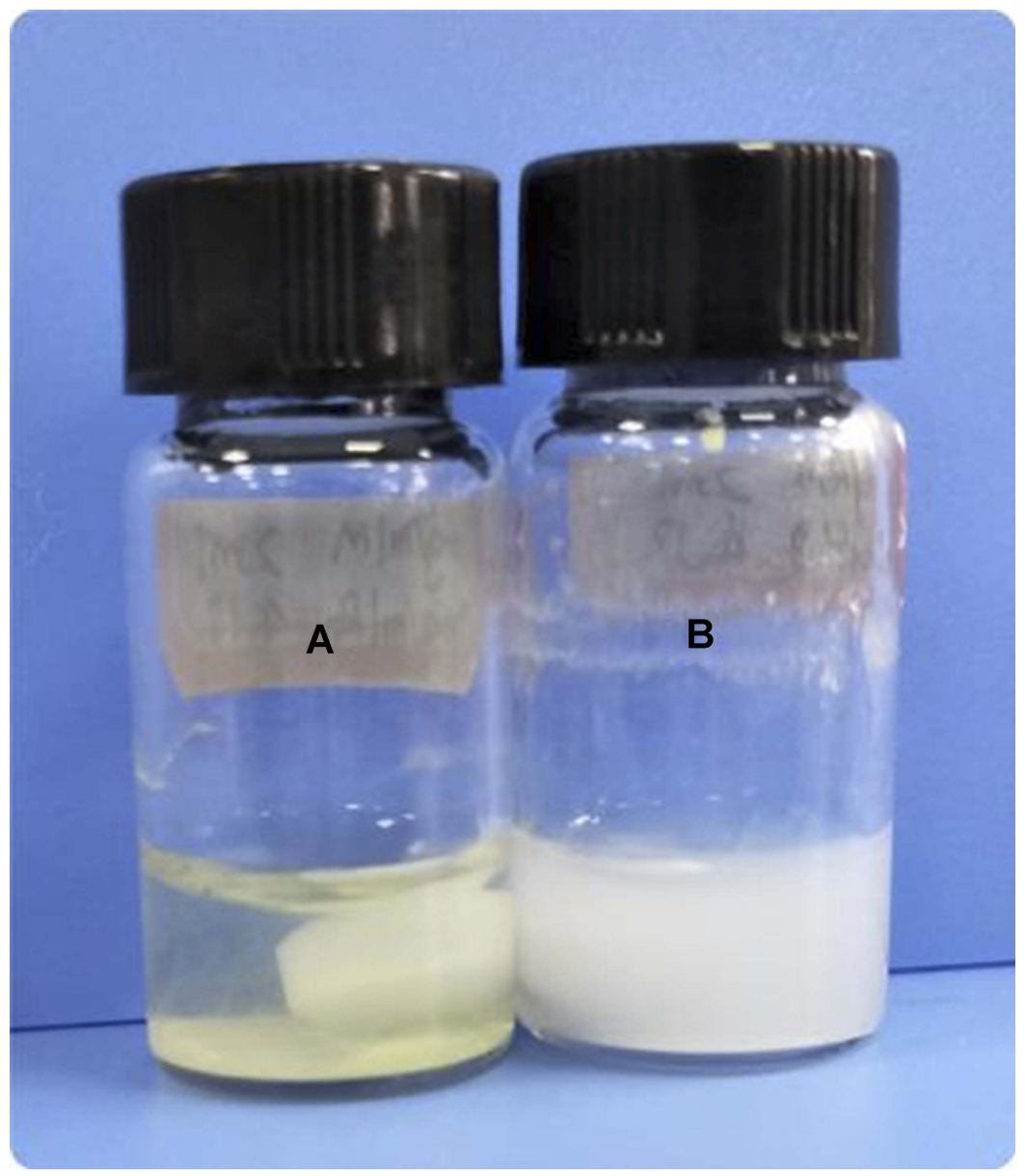

Figure I Formation of a colloidal suspension of RADAI6-I and mangiferin (MA). (A) MA with pure water. (B) MA with RADAI6-I. The photograph was taken after the mixture was magnetically stirred for $24 \mathrm{~h}$. [MA] $=0.5 \mathrm{mg} / \mathrm{mL}$, [RADAI6-I] $=5 \mathrm{mg} / \mathrm{mL}$.

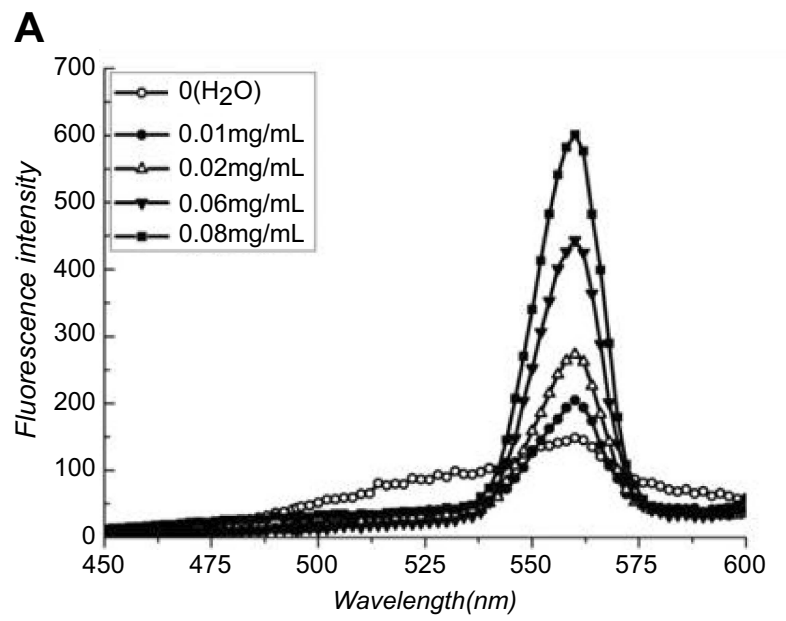

B

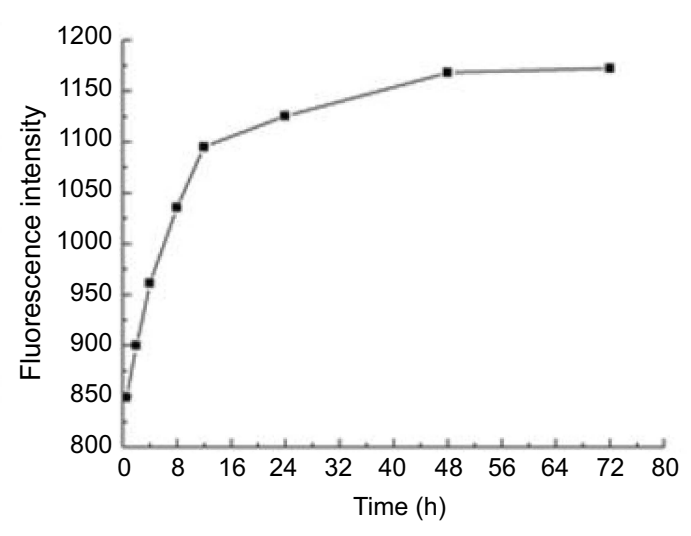

Figure 2 (A) The fluorescence emission spectra of mangiferin (MA, $50 \mu \mathrm{g} / \mathrm{mL}$ ) in aqueous solutions with various concentrations of RADAI6-I (0-0.08 $\mathrm{mg} / \mathrm{mL})$. (B) Fluorescence intensity of MA at $560 \mathrm{~nm}$ in a suspension with RADAI6-I under magnetic stirring at different time points. [MA] $=200 \mu \mathrm{g} / \mathrm{mL}$, [RADAI6-I] $=500 \mu \mathrm{g} / \mathrm{mL}$. The excitation wavelength was set at $277 \mathrm{~nm}$.

domains of the RADA16-I self-assembly. At a higher RADA16-I concentration, relatively more hydrophobic domains can accommodate more MA molecules and decrease exposure of MA to the aqueous phase, and, subsequently, increase fluorescence due to relatively higher fluorescent quantum yield. 
Figure 2B shows fluorescence intensities of MA (200 $\mu \mathrm{g} / \mathrm{mL}$, a concentration higher than the saturated solubility of MA in water) at $560 \mathrm{~nm}$ in a suspension with RADA16-I $(500 \mu \mathrm{g} / \mathrm{mL})$ under magnetic stirring at different time points. After adding RADA16-I for magnetic stirring, the peptide began to interact with MA in the suspension and the interaction between the peptide and MA got stronger with the stirring time. After stirring for about $48 \mathrm{~h}$, the fluorescence intensity of the suspension was basically unchanged. This may reflect a balance of the interaction between MA and RADA16-I in an aqueous suspension.

\section{Maximum suspension ratio of MA in the RADA I6-I-MA suspension}

UV spectrophotometry was used to determine the amount of MA stabilized in suspension by RADA16-I. The calibration curve for MA was linear in the concentration range of $4-14 \mu \mathrm{g} / \mathrm{mL}$, with a correlation coefficient (r) of 0.9991 and a regression equation of $\mathrm{C}=20.1931 \mathrm{~A}-0.8408$. The MA concentration was calculated by calibration curve, and the maximum suspension rate (\%) is shown in Figure 3.

When MA was stirred with water for $48 \mathrm{~h}$, some MA powder attached to the bottom or wall of the vials, and the suspension rate was $48.3 \%$; in the presence of self-assembling peptide, 77-96\% of MA was suspended in the aqueous solutions with RADA16-I concentrations from 0.01 to $0.2 \mathrm{mg} / \mathrm{mL}$. The amount of MA stabilized in RADA16-I aqueous solutions and the suspension rates of MA also increased gradually with an increase of the concentration

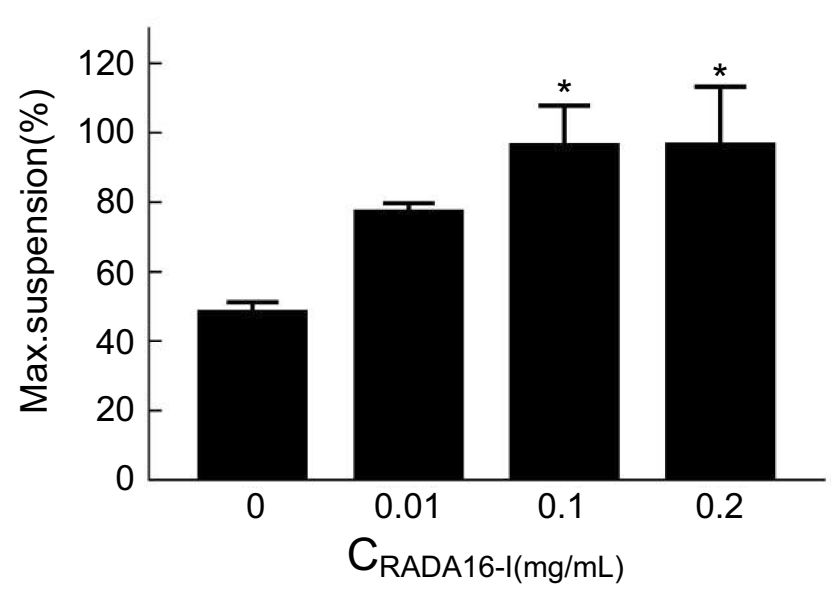

Figure 3 The maximum suspension rate (\%) of mangiferin (MA) in various concentrations of RADAI6-I (0.0I, 0.1 , and $0.2 \mathrm{mg} / \mathrm{mL})$. [MA] $=0.3 \mathrm{mg} / \mathrm{mL}$. Note: ${ }^{*} p<0.05$. of RADA16-I, and $0.3 \mathrm{mg} / \mathrm{mL}$ of MA can be effectively stabilized in suspension with the peptide at a concentration higher than $0.1 \mathrm{mg} / \mathrm{mL}$. The relatively strong interaction between the self-assembling peptide RADA16-I and MA makes the peptide stabilize MA in aqueous suspension at a molar ratio of MA to RADA16-I of about 12:1.

\section{Size distribution of the RADA I6-I-MA suspension}

The particle size distribution of the RADA16-I-MA suspension at different concentrations of RADA16-I was determined by laser particle size analyzer. For a suspension containing various concentrations of the peptide, the particle size distributed between 300 and 600 $\mathrm{nm}$ with a peak distribution at $400 \mathrm{~nm}$. The average particle size of the RADA16-I-MA colloidal suspension was $492 \mathrm{~nm}$ and polydispersity index (PDI) was $<0.3$. The particle size distribution of the water-MA suspension was in the range of $300-2000 \mathrm{~nm}$, and the average particle size was about $810 \mathrm{~nm}$ (Figures 4 and 5).

Dynamic light scattering is conventionally used to examine supramolecular structures in solution or suspension by measuring the average particle size distribution. It was found from dynamic light scattering data that the particle size of the suspension of MA formed with RADA16-I in water had a narrower distribution with a smaller average particle size than that of the water-MA suspension. It is speculated that the interaction makes the MA particles smaller and the colloidal suspension may be formed through the adsorption of RAD16-I onto the surface of MA microcrystals.

\section{Formation of RADA I6-I-MA in situ hydrogel and rheological properties}

The formation of RADA16-I-MA hydrogel is shown in Figure $6 \mathrm{E}$ and $\mathrm{F}$. When being added into $\mathrm{PBS}$, part of the water-MA suspension floated on the surface of the liquid and the rest precipitated at the bottom of the vial; while the RADA16-I-MA suspension rapidly turned into a white milky hydrogel immediately after being added to PBS.

Analysis of the rheological properties of the hydrogel is useful for understanding the viscoelastic nature and strength in shearing action. ${ }^{37,38}$ Figure 6A-D showed the frequency sweep of the RADA16-I hydrogels with or without MA prepared in different concentrations of peptide. As shown in Figure 6A and B, in RADA16-I 

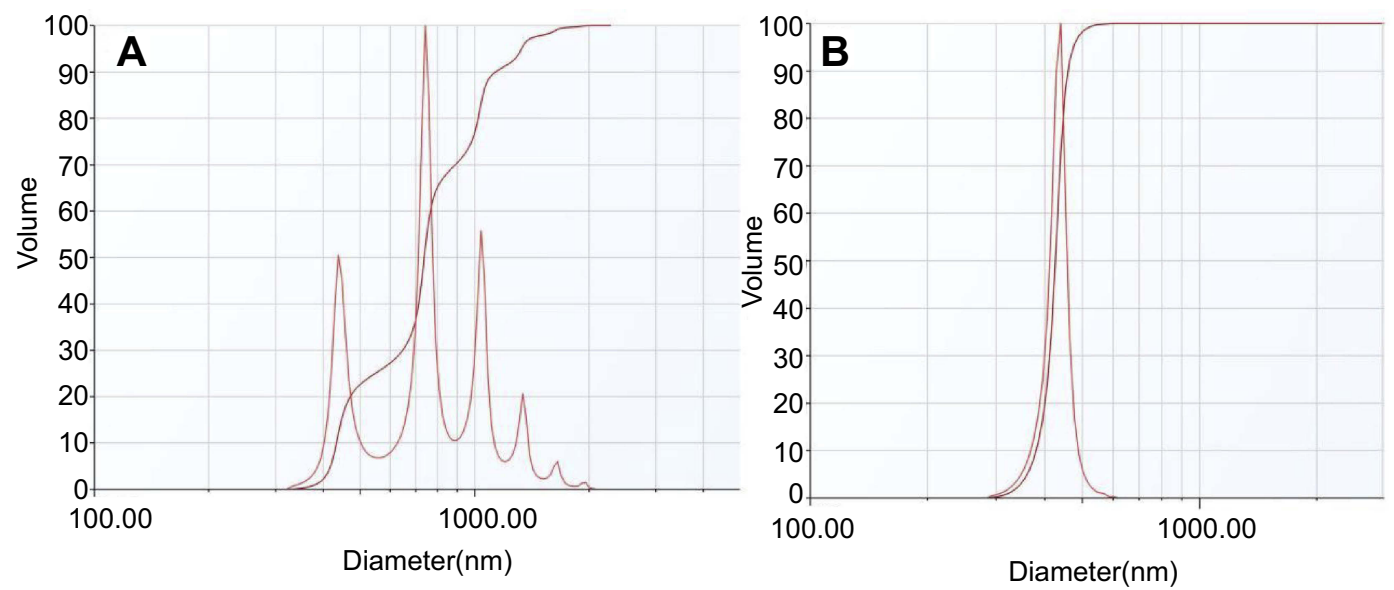

Figure 4 The particle size distribution of the water-mangiferin (MA) suspension (A) and the RADAI6-I-MA suspension (B). The concentration of RADAI6-I and MA was I $\mathrm{mg} / \mathrm{mL}$ and $0.5 \mathrm{mg} / \mathrm{mL}$, respectively.

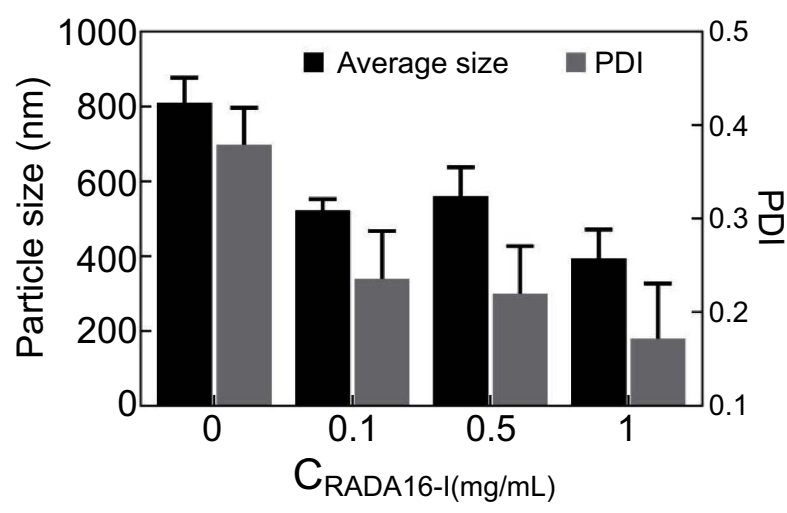

Figure 5 The average particle size of the RADAI6-I-mangiferin (MA) suspension at different concentrations of RADAI6-I $(0.1,0.5$, and I $\mathrm{mg} / \mathrm{mL})$. The concentration of MA was $0.5 \mathrm{mg} / \mathrm{mL}$. The control sample was a water-MA suspension without RADA I6-I. There was no significant difference between the various concentrations of RADA I6-I-MA groups. Abbreviation: PDI, polydispersity index.

solution without PBS, the storage modulus ( $\left.G^{\prime}\right)$ was slightly larger than the loss modulus (G"), and the values of G' and G" are relatively low. The dynamic frequency scan of the sample was carried out in the range of 0.1-10 Hz. For the shear frequency changes, G' and G" showed irregular changes, which signified the high flowability of the solution. When RADA16-I solution was mixed with PBS, G' and G" increased significantly, but the increase in G' was significantly greater than that in G', indicating the formation of a stable hydrogel. In addition, as the concentration of peptides increases, G' and G" also increase significantly. As shown in Figure $6 \mathrm{C}$ and D, the increase in G' and G" of RADA16-I-MA suspension and hydrogel showed a similar trend to RADA16-I solution and hydrogel, and the phase angle $(\Delta)$ values decreased obviously (Table 1).
Oscillatory rheology is widely used to determine the viscoelasticity of hydrogels, in which G' and G" represent the elasticity and viscosity of the material, respectively. An increase in the $G$ ' value means that the material properties are closer to the elastic solid, and an increase in the G" value means the material properties are closer to the viscous liquid. The tangent of the ratio of $\mathrm{G} " / \mathrm{G}$ ' represents $\Delta$, and the decrease in $\Delta$ value usually means that the material is closer to the elastic solid. As shown in Figure 6 and Table 1, for the RADA16-I solution and the RADA16-I-MA suspension, the $G^{\prime}$ and $G$ ' values were all around $10 \mathrm{~Pa}$, indicating that the material formed a low-elastic and lowviscosity system at that time; when RADA16-I and the RADA16-I-MA solution were mixed with PBS by equal volume, the G' and G" values increased significantly, but the increase of G' was significantly larger than that of G" and the $\Delta$ value decreased significantly, indicating that the behavioral characteristics of the system gradually change from viscous liquid to elastic solid. It is further illustrated that RADA16-I aqueous solution can form a hydrogel with certain hardness and cross-linking structures when mixed with PBS. It seems that MA did not interfere with the formation of the hydrogel.

In addition, after the RADA16-I solution and RADA16-I-MA suspension were mixed with PBS, the G' and G" values remained constant with increasing frequency. It was noted in our test range that the RADA16-I solution without drug and the RADA16-I-MA suspension can be slightly affected by the scanning frequency, while both the RADA16-I hydrogel and the RADA16-I-MA hydrogel were significantly more stable to withstand external forces than their solution or suspension state before 
A

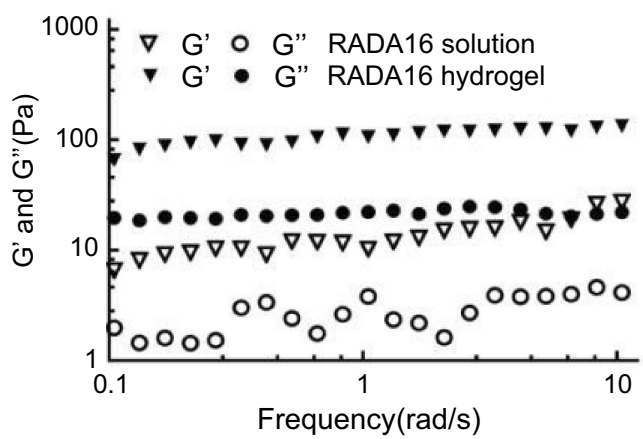

B

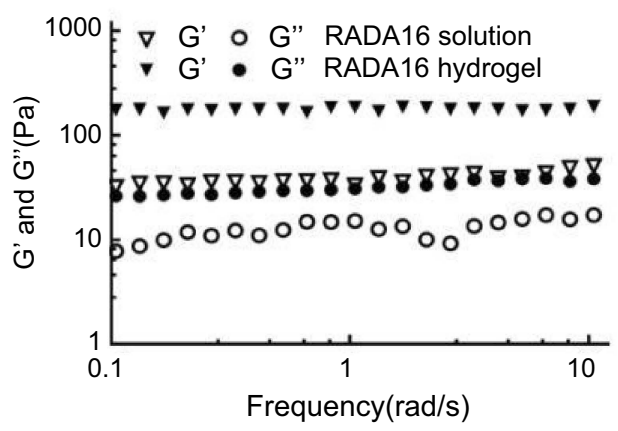

C

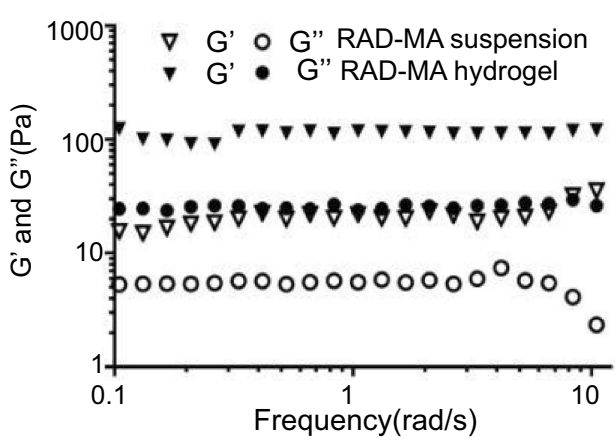

D

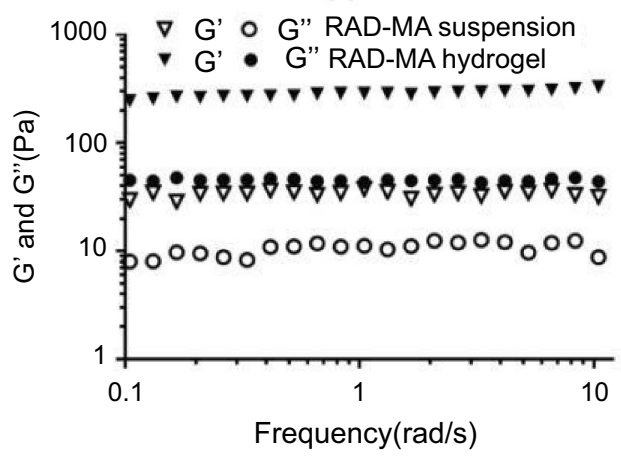

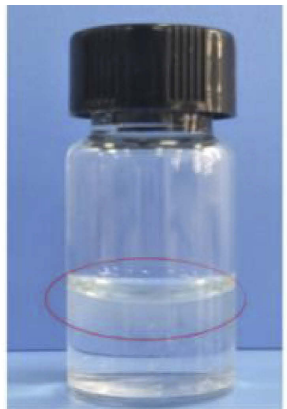

$\mathbf{E}$

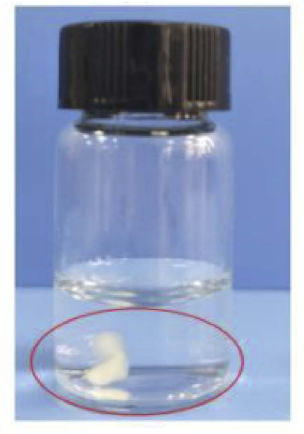

F

Figure 6 The rheological properties of RADA I6-I-mangiferin (MA) suspension and RADAI6-I-MA hydrogel. (A) $5 \mathrm{mg} / \mathrm{mL}$ RADAI6-I solution and hydrogel. (B) I0 mg/mL RADA I6-I solution and hydrogel. (C) $5 \mathrm{mg} / \mathrm{mL}$ RADAI6-I-MA suspension and hydrogel. (D) $10 \mathrm{mg} / \mathrm{mL}$ RADAI6-I-MA suspension and hydrogel. (E) The water-MA suspension in PBS. (F) The RADAI6-I-MA suspension in PBS.

Abbreviations: G', storage modulus; G", loss modulus.

Table I Viscoelastic properties characteristics of RADA I6-I and RADA I6-I-mangiferin (MA) hydrogel

\begin{tabular}{|c|c|c|c|c|c|c|}
\hline \multicolumn{7}{|c|}{ Concentration of RADA I6-I } \\
\hline \multirow[t]{2}{*}{ Group } & \multicolumn{3}{|c|}{$5 \mathrm{mg} / \mathrm{mL}$} & \multicolumn{3}{|c|}{$10 \mathrm{mg} / \mathrm{mL}$} \\
\hline & G' & G” & $\Delta$ & G' & G” & $\Delta$ \\
\hline RADAI6-I solution & 10.25 & 3.82 & 20.44 & 33.26 & 15.15 & 24.49 \\
\hline RADAI6-I Hydrogel & 105.64 & 22.20 & 11.87 & 185.90 & 30.92 & 9.44 \\
\hline RADAI6-I-MA suspension & 21.94 & 5.58 & 14.27 & 37.73 & 11.19 & 16.52 \\
\hline RADA I6-I-MA Hydrogel & 118.29 & 23.88 & 11.42 & 287.87 & 43.32 & 8.56 \\
\hline
\end{tabular}

Abbreviations: $\Delta$, phase angle; G', storage modulus; G", loss modulus.

they were mixed with PBS. Meanwhile, with a concentration increase of the peptide, the $\Delta$ value of the hydrogel decreased significantly, indicating that a higher concentration of the peptide can make the system much closer to the elastic solid and greater in the strength of the hydrogel. This may be related to the packing strength of the peptide. Therefore, the self-assembling peptide RADA16-I may be capable of encapsulation and sustained release of the drug as a stable injectable drug carrier or hydrogel matrix for tumor or local administration. The greater strength the hydrogel has, the tighter the encapsulation will be and thus the slower the release of the drugs loaded in the hydrogel. That is to say, the strength of the hydrogel may be useful to improve encapsulation and to adjust release of the drug by changing the types or concentrations of peptide.

\section{In vitro drug release from RADA I6-I-MA}

\section{hydrogel}

Method development

Specificity

The MA samples had absorption peaks at 240, 258, 319, and 


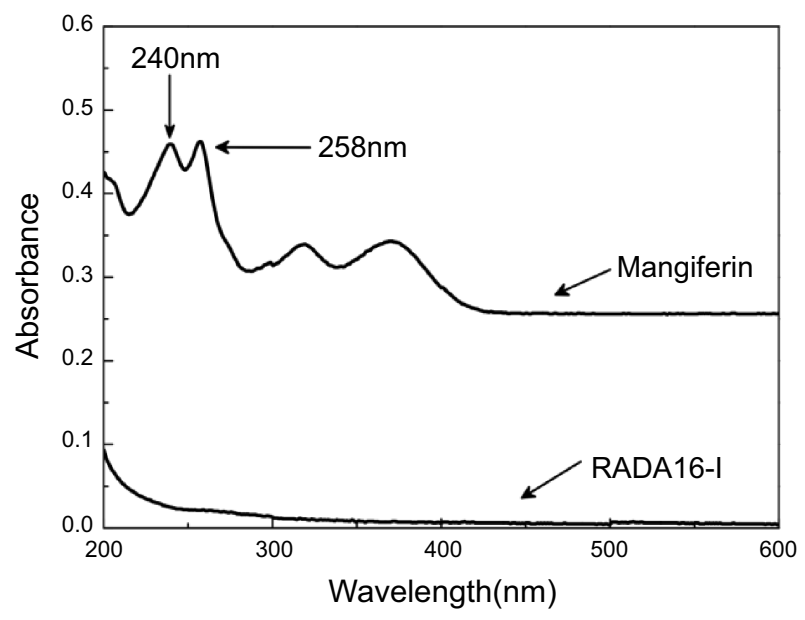

Figure 7 The ultraviolet spectra of blank RADA I6-I solution and $4 \mu \mathrm{g} / \mathrm{mL}$ mangiferin solution.

$370 \mathrm{~nm}$; the samples had maximum absorption at $240 \mathrm{~nm}$ and RADA16-I did not affect the absorption of MA. Therefore, $240 \mathrm{~nm}$ was selected as the detection wavelength (Figure 7).

\section{Linearity}

The calibration curve for MA was linear in the concentration range of $3.2-8.0 \mu \mathrm{g} / \mathrm{mL}$ in release medium, with a regression equation of $\mathrm{C}=9.8155 \mathrm{~A}+0.6609$ and a correlation coefficient $\left(\mathrm{r}^{2}\right)$ of 0.9995 .

\section{Recovery rate of MA}

The sample solutions of MA with known concentration were taken, and the MA reference solution was added in a ratio of $1.5: 1,1: 1$, and $0.5: 1$ of the amount of MA in the reference solution to that in the samples. Then, the absorbance of MA was measured at $240 \mathrm{~nm}$ and the recovery of MA was calculated by comparing the actual measurement with the added value based on the absorbance values. The average recovery of MA with high, medium, and low concentrations in PBS ( $\mathrm{pH} 7.4$ ) containing 0.3\% SDS were $101.51 \%, 99.32 \%$, and $99.11 \%$, with RSD (relative standard deviation) of $1.08 \%$. The recovery value was between 98 and $102 \%$ and the RSD value was less than $2.0 \%$, which indicates that the recovery rate meets the methodological requirements and the method had high accuracy.

\section{Drug release}

The release profile of MA from the different concentrations of RADA16-I-MA hydrogel is shown in Figure 8 (the inset illustration in the figure is an enlarged view of the release trend of the first $6 \mathrm{~h}$ of the sample). MA is a slightly water-

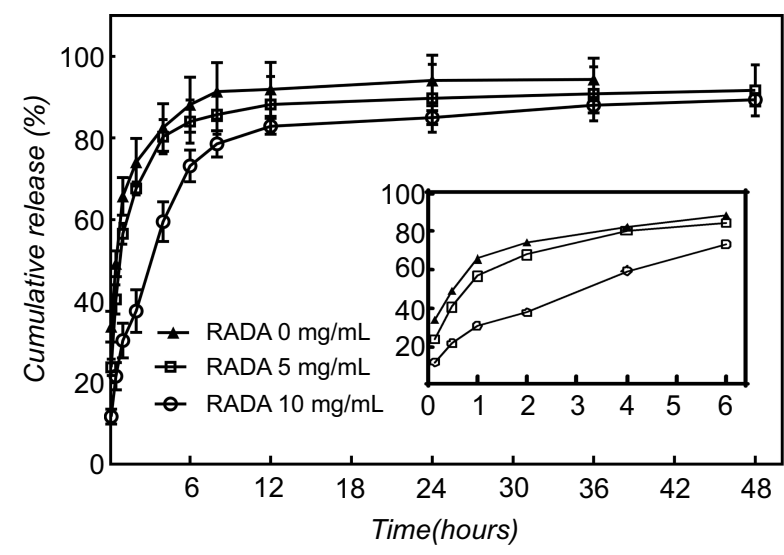

Figure 8 The cumulative release of mangiferin from drug-loaded peptide hydrogel with different RADAI6-I concentrations. The RADAI6-I concentration was 5 mg/ $\mathrm{mL}$ and $10 \mathrm{mg} / \mathrm{mL}$.

soluble drug. To maintain sink conditions, $0.3 \%$ of SDS was added to the release medium to increase the solubility of MA. MA in pure water suspension presented faster release than in hydrogels with the self-assembling peptide RADA16-I; about $91.4 \%$ of MA was released within 8 h, and all MA was released within $24 \mathrm{~h}$. The relatively slower release was observed in the release of MA from the hydrogels with the peptide RADA16-I at different concentrations. In addition, the release of MA from hydrogel with $10 \mathrm{mg}$ / mL RADA16-I was slower than that from $5 \mathrm{mg} / \mathrm{mL}$, which suggests that the release of MA from the self-assembling peptide hydrogel can be adjusted by the concentration of the self-assembling peptide RADA16-I. The RADA16-MA hydrogels showed sustained drug release for at least $48 \mathrm{~h}$. This can be related to the interaction between the selfassembling peptide and MA and the network structure of the RADA16-I hydrogel.

The ionic-complementary self-assembling peptide RADA16-I has been reported to stabilize the hydrophobic compound pyrene. $^{39,40}$ The hydrophobic region of RADA16-I can interact with hydrophobic compounds, while the charged residues stabilize the complex in aqueous solutions. With the addition of cations or physiological media, or a change of $\mathrm{pH}$ value to neutral, the self-assembling peptides undergo gelation into a macroscopic hydrogel, which contains over $99 \%(\mathrm{~W} / \mathrm{V})$ water with a $10 \mathrm{~nm}$ fiber diameter and a 5-200 $\mathrm{nm}$ pore size, a similar nanostructure to the natural extracellular matrix. ${ }^{41}$ In this research, a colloidal suspension containing the self-assembling peptide RADA16I and MA was formed in water under magnetic stirring; a hydrogel was rapidly formed when the suspension was added to PBS. The three-dimensional network of nanofiber 
Table 2 RADA I6-I-MA hydrogel release model fitting

\begin{tabular}{|c|c|c|c|c|c|}
\hline \multirow{2}{*}{$\begin{array}{l}\text { C }_{\text {RADA I6-I }} \\
(\mathrm{mg} / \mathrm{mL})\end{array}$} & & \multicolumn{4}{|l|}{ Model } \\
\hline & & Zero-order kinetics & First-order kinetics & Higuchi & Riter-peppas \\
\hline 0 & $\begin{array}{l}\text { Equation } \\
\mathrm{R}^{2}\end{array}$ & $\begin{array}{l}M_{t}=1.04 k-49.13 \\
0.4591\end{array}$ & $\begin{array}{l}M_{t}=89.88\left(I-e^{-1.21 t}\right) \\
0.9773\end{array}$ & $\begin{array}{l}M_{t}=8.2 I t^{1 / 2}+40.32 \\
0.6970\end{array}$ & $\begin{array}{l}M_{t}=45.43 t^{0.24} \\
0.8514\end{array}$ \\
\hline 5 & $\begin{array}{l}\text { Equation } \\
\mathrm{R}^{2}\end{array}$ & $\begin{array}{l}M_{t}=1.62 k-50.75 \\
0.2650\end{array}$ & $\begin{array}{l}M_{t}=76.22\left(I-e^{-1.43 t}\right) \\
0.9622\end{array}$ & $\begin{array}{l}M_{t}=10.58 t^{1 / 2}+34.66 \\
0.5792\end{array}$ & $\begin{array}{l}M_{t}=52.68 t^{0.19} \\
0.6827\end{array}$ \\
\hline 10 & $\begin{array}{l}\text { Equation } \\
R^{2}\end{array}$ & $\begin{array}{l}M_{t}=0.84 k-55.59 \\
0.4024\end{array}$ & $\begin{array}{l}M_{t}=92.30\left(I-e^{-1.08 t}\right) \\
0.9895\end{array}$ & $\begin{array}{l}M_{t}=8.52 t^{1 / 2}+37.14 \\
0.6366\end{array}$ & $\begin{array}{l}M_{t}=50.07 t^{0.18} \\
0.8129\end{array}$ \\
\hline
\end{tabular}

Abbreviation: $\mathrm{R}^{2}$, determination coefficient; $M_{t}$, cumulative release of $M A$; $k$, zero-order speed constant.

structures in the hydrogel contains hydrophilic and hydrophobic regions whose hydrophobic regions can interact with the hydrophobic drug MA. The hydrophobic drug MA is supposed to reside within the hydrophobic regions of the nanostructures in the hydrogel where the smaller pores and MA-nanofiber interaction may be hindrances to the diffusion of the hydrophobic drug MA.

As can be seen from the inset illustration in Figure 8, in the MA aqueous suspension without the self-assembling peptide RADA16-I there was a significant burst release of MA during the first $15 \mathrm{~min}$, and the cumulative release was about $38 \%$ at $15 \mathrm{~min}$ and $75 \%$ at $2 \mathrm{~h}$; while in hydrogels containing $10 \mathrm{mg} /$ $\mathrm{mL}$ of the peptide, the cumulative release of MA was about $12 \%$ at $15 \mathrm{~min}$ and $39 \%$ at $2 \mathrm{~h}$. It was indicated that the selfassembling peptide hydrogel can slow the release of MA and limit the burst release of MA in the initial stage of release to some extent.

\section{Release model}

In order to quantificationally describe the release of MA, the Origin program was used to fit the release model and calculate the model parameters and the determination coefficient $\left(\mathrm{R}^{2}\right)$.
In this study, four models (zero-order, first-order, Higuchi, and Ritger-Peppas) were used to fit the kinetic profile of MA release from the hydrogel. The fitted equation and the determination coefficients $\left(\mathrm{R}^{2}\right)$ are presented in Table 2. The firstorder kinetics model is the best to describe the kinetic profile, as indicated by the highest $R^{2}$ values.

\section{In vitro cell viability test}

The effects of MA on cell viability in the presence and absence of the hydrogel were determined to test the safety and effectiveness of the delivery system in vitro. In this study, we investigated the effects of free MA and RADA16-I-MA in situ hydrogels on cell viability of KYSE 30, DLD-1, and 293T cells by the Cell Counting Kit 8 method.

When RADA16-I-MA and free MA were cocultured with the 293T cells, normal human renal epithelial cells, for a certain period of time, the survival rate of the cells incubated with RADA16-I-MA and MA decreased with an increase in the concentration of MA. But overall, the toxicity of free MA to 293T cells is higher than that of the RADA16-I-MA in situ hydrogel (Figure 9).

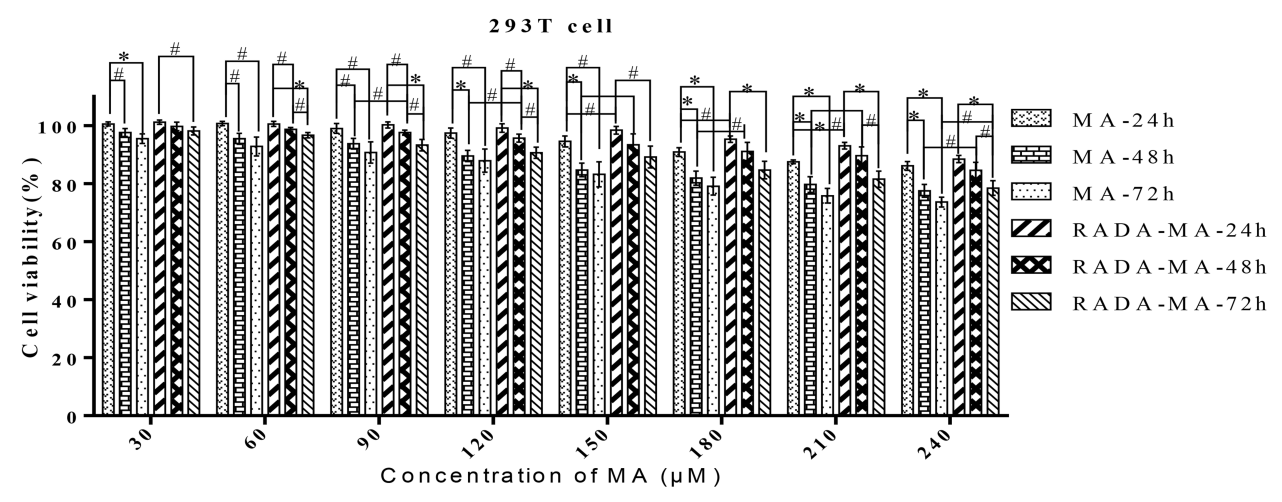

Figure 9 Cellular toxicity of RADAI6-I-mangiferin (MA) in situ hydrogel and free MA on 293T cells. [RADAI6-I] $=5 \mathrm{mg} / \mathrm{mL}$; data calculated from three independent experiments. Notes: ${ }^{\#} P<0.05, * P<0.01$. 

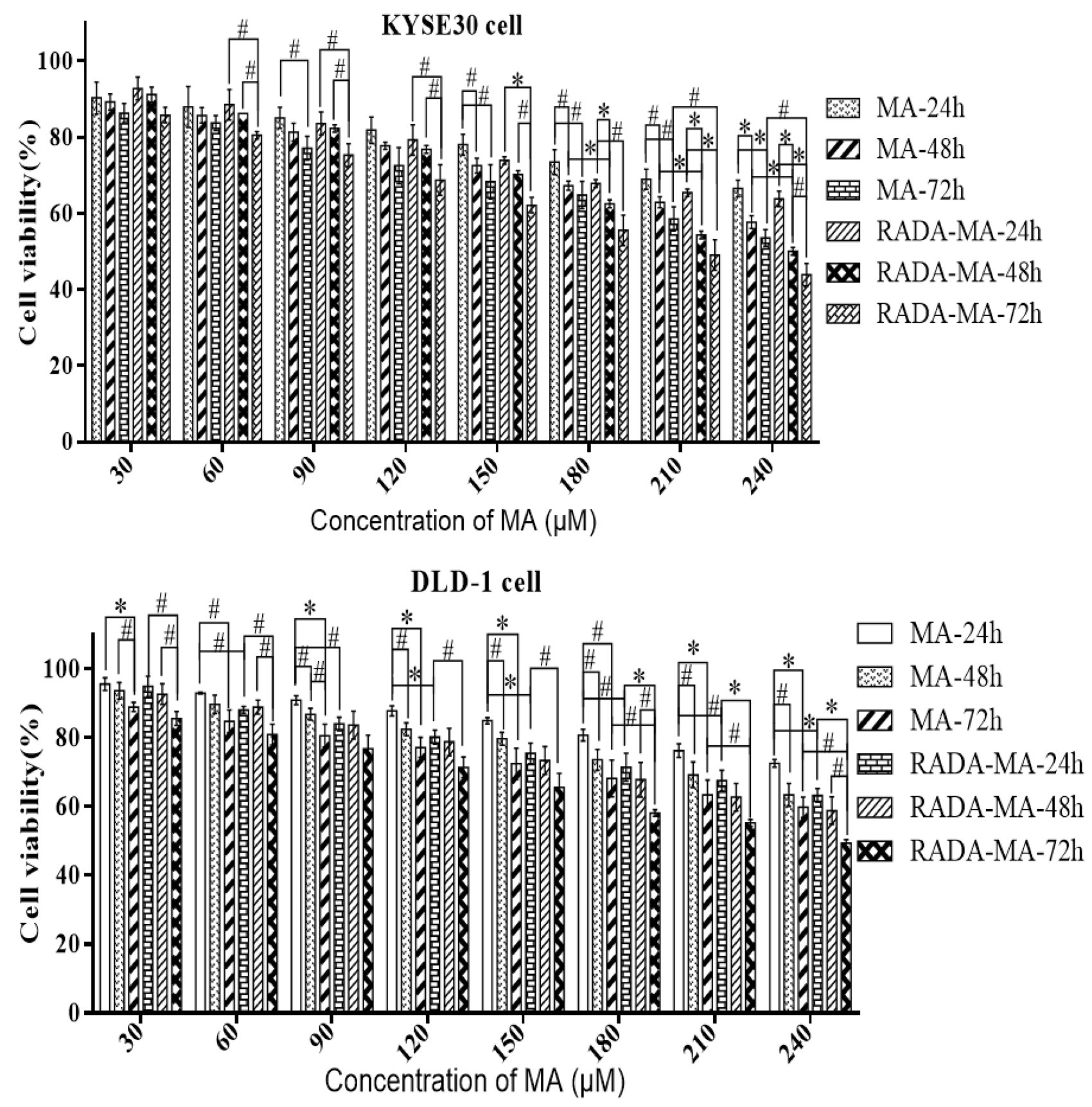

Figure 10 Proliferation inhibition effects of free MA and RADA I6-I-MA in situ hydrogel on KYSE 30 and DLD-I cells incubated for 24, 48, and 72 h. [RADAI6-I]=5 mg/mL; data calculated from three independent experiments.

Notes: ${ }^{\#} P<0.05,{ }^{*} P<0.01$.

The proliferation inhibition effects of different concentrations of free MA and MA-loaded hydrogel on KYSE30 and DLD-1 cell lines at each time point are shown in Figure 10. The inhibition effects of MA-loaded hydrogels on two tumor cells at each time point were all stronger than that of the equal concentrations of the MA solution. At 24, 48 , and $72 \mathrm{~h}$, with the increase of drug concentration, the inhibition rates of MA-loaded hydrogels and MA solution on tumor cells all increased. On the whole, the inhibitory effects of RADA16-I-MA in situ hydrogel on tumor cells were stronger than that of free MA. The experimental results showed that the self-assembling RADA16-I-MA hydrogel can enhance the anticancer activity of MA in vitro.

It is becoming increasingly clear that changes in the administration of drugs can greatly impact efficacy, and some researchers believe that the hydrogel is an excellent 
candidate as a local drug delivery vehicle for hydrophobic drugs. $^{42-44}$ In this research, both the proliferation inhibition effects on tumor cells of free MA and MA in peptide-MA in situ hydrogel showed concentration- and time-dependent manners, and the in situ hydrogel had better antitumor effects than that of the free drug with statistical significance. The reason for this may be that MA is poorly water-soluble and the free MA is easy to precipitate in the cell culture. The delivery system in this research is a self-assembling peptide-based suspension in situ hydrogel for the hydrophobic drug MA. When the effects of MA in the self-assembling peptide in situ hydrogel on cell viability are tested, adding the correct amount of RADA16-I-MA colloidal suspension (prepared by magnetically stirring the selfassembling peptide RADA16-I and MA in water) can increase the solubility of MA in water and improve the administration of MA into the cell culture and the suspension can rapidly turn into a hydrogel in situ. In this process, the self-assembling peptide RADA16-I can help increase the solubility of MA in water and guarantee relatively stable and uniform administration of MA, so the in situ hydrogel had better antitumor effects than the free drug. The lower cytotoxicity on normal cells of MA in the peptide-MA in situ hydrogel than in free MA can be related to the slow release and limited burst release of MA from the in situ hydrogel. In summary, the peptide RADA16-I can be helpful for improving the administration, enhancing antitumor effects, and reducing toxicity to normal cells of MA.

\section{Conclusions}

RADA16-I-MA colloidal suspensions can spontaneously form in situ hydrogel under physiological condition. MA encapsulated in the RADA16-I hydrogels can be released from the hydrogel slowly and the release rate can be controlled by adjusting the concentration of the peptide to achieve the sustained-release effect. These results further demonstrated that self-assembling peptides like RADA16-I have great potential to be carriers for hydrophobic drugs like MA.

This work will enhance understanding of the interaction between self-assembling peptides and hydrophobic drugs and promote the delivery system in encapsulating and releasing hydrophobic drugs with self-assembling peptides. The carrier presented in this research has the potential to be applied in administration at sites of eye, tumor, skin, or local surgery. Further in vivo animal experiments of this delivery system need to be carried out; the problems related to the material cost of the self-assembling peptide and other specific drug-forming properties of the system need further work to achieve practical application of the carrier system in this research.

\section{Acknowledgments}

This work was financially supported by the National Natural Science Foundation of China (No. 31460246), the 2011 Collaborative Innovation Center of Guizhou Traditional Chinese Medicine and Ethnic Medicine (No. Qianjiaokeyanfa (2012) 311), the Education Department of Guizhou Province of China (No. GNYL (2017) 006 and YLXKJS-YS-05), and the Guizhou Provincial and Municipal Science and Technology Cooperation Special Fund Project (No. Shengshikehe (2015) 53). Great thanks goes to the Army Medical University School of Pharmaceutics for rheological measurement and to the State Key Laboratory of Molecular Oncology, Cancer Hospital, Chinese Academy of Medical Sciences, Peking Union Medical College for cell experiments.

\section{Disclosure}

The authors report no conflicts of interest in this work.

\section{References}

1. Qiu F, Chen Y, Tang C, et al. Self-assembling surfactant-like peptide $\mathrm{A}_{6} \mathrm{~K}$ as potential delivery system for hydrophobic drugs. Int $J$ Nanomedicine. 2015;10:847-858. doi:10.2147/IJN.S71696

2. Qi X, Wei W, Li J, et al. Design of Salecan-containing semi-IPN hydrogel for amoxicillin delivery. Mater Sci Eng C. 2017;75:487494. doi:10.1016/j.msec.2017.02.089

3. Koutsopoulos S. Self-assembling peptide nanofiber hydrogels in tissue engineering and regenerative medicine: progress, design guidelines, and applications. J Biomed Mater Res A. 2016;104(4):1002-1016. doi:10.1002/jbm.a.35638

4. Zhao X. Design of self-assembling surfactant-like peptides and their applications. Curr Opin Colloid In. 2009;14(5):340-348. doi:10.1016/ j.cocis.2009.07.002

5. Ganguly S, Das NC. Water uptake kinetics and control release of agrochemical fertilizers from nanoclay-assisted semi-interpenetrating sodium acrylate-based hydrogel. Polym Plast Technol Eng. 2017;56 (7):744-761. doi:10.1080/03602559.2016.1233268

6. Qi X, Wei W, Shen J, et al. Salecan polysaccharide-based hydrogels and their applications: a review. J Mater Chem B. 2019;7:2577-2587. doi:10.1039/C8TB03312A

7. Eskandari S, Guerin T, Toth I, et al. Recent advances in self-assembled peptides: implications for targeted drug delivery and vaccine engineering. Adv Drug Deliv Rev. 2016;110-111:169-187. doi:10. 1016/j.addr.2016.06.013

8. Banerjee J, Radvar E, Azevedo HS. Self-assembling peptides and their application in tissue engineering and regenerative medicine. In: Barbosa MAM, Martins CL, editors. Peptides and Proteins as Biomaterials for Tissue Regeneration and Repair. Cambridge: Woodhead Publishing; 2018:245-281.

9. Koutsopoulos S. Self-assembling peptides in biomedicine and bioengineering: tissue engineering, regenerative medicine, drug delivery, and biotechnology. In: Koutsopoulos S, editor. Peptide Applications in Biomedicine, Biotechnology and Bioengineering. Cambridge: Woodhead Publishing; 2018:387-408. 
10. Moore AN, Hartgerink JD. Self-assembling multidomain peptide nanofibers for delivery of bioactive molecules and tissue regeneration. Acc Chem Res. 2017;50(4):714-722. doi:10.1021/acs.accounts. $6 \mathrm{~b} 00553$

11. Sever M, Tansik G, Arslan E, et al. Self-assembled peptide nanostructures and their gels for regenerative medicine applications. In: Azevedo HS, Silva RMP, editors. Self-assembling Biomaterials. Cambridge: Woodhead Publishing; 2018:455-473.

12. Wu X, He L, Li W, et al. Functional self-assembling peptide nanofiber hydrogel for peripheral nerve regeneration. Regen Biomater 2017;4(1):21-30. doi:10.1093/rb/rbw034

13. Wang X, Wang J, Guo L, et al. Self-assembling peptide hydrogel scaffolds support stem cell-based hair follicle regeneration. Nanomed-Nanotechnol. 2016;12(7):2115-2125. doi:10.1016/j.nano. 2016.05.021

14. Krukiewicz K, Zak JK. Biomaterial-based regional chemotherapy: local anticancer drug delivery to enhance chemotherapy and minimize its side-effects. Mater Sci Eng C Mater Biol Appl. 2016;62 (3):927-942. doi:10.1016/j.msec.2016.01.063

15. Zhang J, Ellsworth K, Ma PX. Hydrophobic pharmaceuticals mediated self-assembly of beta-cyclodextrin containing hydrophilic copolymers: novel chemical responsive nano-vehicles for drug delivery. J Controlled Release. 2010;145(2):116-123. doi:10.1016/j. jconrel.2010.04.019

16. Qi X, Wei W, Li J, et al. Fabrication and characterization of a novel anticancer drug delivery system: salecan/poly (methacrylic acid) semi-interpenetrating polymer network hydrogel. ACS Biomater Sci Eng. 2015;1(12):1287-1299. doi:10.1021/acsbiomaterials.5b00346

17. Zhou J, O'Keeffe M, Xu B, et al. Design and synthesis of nanofibers of self-assembled de novo glycoconjugates towards mucosal lining restoration and anti-inflammatory drug delivery. Tetrahedron. 2016;72(40):6078-6083. doi:10.1016/j.tet.2016.07.057

18. Fung SY, Yang H, Bhola PT, et al. Self-assembling peptide as a potential carrier for hydrophobic anticancer drug ellipticine: complexation, release and in vitro delivery. Adv Funct Mater. 2009;19 (1):74-83. doi:10.1002/adfm.200800860

19. Lu Y, Zhao X. Fluorescence studies on a designed peptide of REIP as a potential hydrophobic drug carrier. Int $J$ Pept Res Ther 2011;17:81-86. doi:10.1007/s10989-011-9245-0

20. Li F, Wang J, Tang F, et al. Fluorescence studies on a designed selfassembling peptide of RAD16-II as a potential carrier for hydrophobic drug. J Nanosci Nanotechno. 2009;9(2):1611-1614. doi:10.1166/ jnn.2009.C214

21. Zhou Q, Lin J, Wang J, et al. A designed amphiphilic peptide containing the silk fibroin motif as a potential carrier of hydrophobic drugs. Prog Nat Sci-Mater. 2009;19(11):1529-1536. doi:10.1016/j. pnsc.2009.04.010

22. Ganguly S, Das NC. Synthesis of a novel $\mathrm{pH}$ responsive phyllosilicate loaded polymeric hydrogel based on poly (acrylic acid-co-N-vinylpyrrolidone) and polyethylene glycol for drug delivery: modelling and kinetics study for the sustained release of an antibiotic drug. RSC $A d v$. 2015;5(24):18312-18327. doi:10.1039/C4RA16119J

23. Qi X, Wei W, Li J, et al. Salecan-based $\mathrm{pH}$-sensitive hydrogels for insulin delivery. Mol Pharm. 2017;14(2):431-440. doi:10.1021/acs. molpharmaceut.6b00875

24. Ganguly S, Maity T, Mondal S, Das P, Das NC. Starch functionalized biodegradable semi-IPN as a $\mathrm{pH}$-tunable controlled release platform for memantine. Int J Biol Macromol. 2017;95:185-198. doi:10.1016/ j.ijbiomac.2016.11.055

25. Qi X, Yuan Y, Zhang J, et al. Oral administration of salecan-based hydrogels for controlled insulin delivery. J Agric Food Chem. 2018;66(40):10479-10489. doi:10.1021/acs.jafc.8b02879

26. Mei L, Xie Y, Huang Y, et al. Injectable in situ forming gel based on lyotropic liquid crystal for persistent postoperative analgesia. Acta Biomater. 2018;67:99-110. doi:10.1016/j.actbio.2017.11.057
27. Ganguly S, Ray D, Das $\mathrm{P}$, et al. Mechanically robust dual responsive water dispersible-graphene based conductive elastomeric hydrogel for tunable pulsatile drug release. Ultrason Sonochem. 2018;42:212-227. doi:10.1016/j.ultsonch.2017.11.028

28. Montes A, Wehner L, Pereyra C, et al. Mangiferin nanoparticles precipitation by supercritical antisolvent process. J Supercrit Fluid. 2016;112:44-50. doi:10.1016/j.supflu.2016.02.008

29. Carvalho AC, Guedes MM, Souza AL, et al. Gastroprotective effect of mangiferin, a xanthonoid from Mangifera indica, against gastric injury induced by ethanol and indomethacin in rodents. Planta Med. 2007;73(13):1372-1376. doi:10.1055/s-2007-990231

30. Malherbe CJ, Willenburg E, de Beer D, et al. Iriflophenone-3-Cglucoside from Cyclopia genistoides: isolation and quantitative comparison of antioxidant capacity with mangiferin and isomangiferin using on-line HPLC antioxidant assays. J Chromatogr B. 2014;951952(1):164-171. doi:10.1016/j.jchromb.2014.01.038

31. He L, Peng X, Zhu J, et al. Mangiferin attenuates sepsis-induced acute kidney injury via antioxidant and anti-inflammatory effects. $\mathrm{Am}$ $J$ Nephrol. 2014;40(5):441-450. doi:10.1159/000369220

32. Rajendran P, Jayakumar T, Nishigaki I, et al. Immunomodulatory effect of mangiferin in experimental animals with benzo (a) pyreneinduced lung carcinogenesis. Int J Biomed Sci. 2013;9(2):68-74.

33. Mahali SK, Manna SK. Beta-D-glucoside protects against advanced glycation end products (AGEs)-mediated diabetic responses by suppressing ERK and inducing PPAR gamma DNA binding. Biochem Pharmacol. 2012;84(12):1681-1690. doi:10.1016/j.bcp.2012.09.033

34. Song J, Li Y, Song J, et al. Mangiferin protects mitochondrial function by preserving mitochondrial hexokinase-II in vessel endothelial cells. BBA-Mol Basis Dis. 2017;1863(7):1829-1839. doi:10.1016/j. bbadis.2017.05.001

35. Liu Y, Xu F, Zeng X, et al. Application of a liquid chromatography/ tandem mass spectrometry method to pharmacokinetic study of mangiferin in rats. $J$ Chromatogr B. 2010;878(32):3345-3350. doi:10.1016/j.jchromb.2010.10.014

36. Souza JRRD, Feitosa JPA, Ricardo NMPS, et al. Spray-drying encapsulation of mangiferin using natural polymers. Food Hydrocolloid. 2013;33(1):10-18. doi:10.1016/j.foodhyd.2013.02.017

37. Ganguly S, Poushali D, Prasanna MP, et al. Green reduced graphene oxide toughened semi-IPN monolith hydrogel as dual responsive drug release system: rheological, physico-mechanical and electrical evaluations. J Phys Chem B. 2018;122(29):7201-7218. doi:10.1021/ acs.jpcb.8b02919

38. Ganguly S, Das NC. Rheological properties of polymer-carbon composites. In: Rahaman M, Khastgir D, Aldalbahi AK, editors. CarbonContaining Polymer Composites. Singapore: Springer; 2019:271-294.

39. Tang F, Zhao X. Interaction between a self-assembling peptide and hydrophobic compounds. Journal of biomaterials science. J Biomat Sci-Polym E. 2010;21(5):677-690. doi:10.1163/156856209X434683

40. Fung SY, Yang H, Chen P. Formation of colloidal suspension of hydrophobic compounds with an amphiphilic self-assembling peptide. Colloids Surf B Biointerfaces. 2007;55(2):00-211. doi:10.1016/ j.colsurfb.2006.12.002

41. Meng Q, Yao S, Wang X, et al. RADA16: a self-assembly peptide hydrogel for the application in tissue regeneration. $J$ Biomate Tiss Eng. 2014;4(12):1019-1029. doi:10.1166/jbt.2014.1246

42. Majumder P, Baxa U, Walsh STR, et al. Design of a multicompartment hydrogel that facilitates time-resolved delivery of combination therapy and synergized killing of glioblastoma. Angew Chem Int Ed Engl. 2018;57(46):15040-15044. doi:10.1002/anie.201806483

43. Sun JEP, Stewart B, Litan A, et al. Sustained release of active chemotherapeutics from injectable-solid $\beta$-hairpin peptide hydrogel. Biomater Sci. 2016;4(5):839-848. doi:10.1039/c5bm00538h

44. Ganguly S, Das NC. Synthesis of mussel inspired polydopamine coated halloysite nanotubes based semi-IPN: an approach to fine tuning in drug release and mechanical toughening. Macromol Symp. 2018;382(1):1800076. doi:10.1002/masy.201800076 


\section{Publish your work in this journal}

The International Journal of Nanomedicine is an international, peerreviewed journal focusing on the application of nanotechnology in diagnostics, therapeutics, and drug delivery systems throughout the biomedical field. This journal is indexed on PubMed Central, MedLine, CAS, SciSearch ${ }^{\circledR}$, Current Contents ${ }^{\circledR} /$ Clinical Medicine,
Journal Citation Reports/Science Edition, EMBase, Scopus and the Elsevier Bibliographic databases. The manuscript management system is completely online and includes a very quick and fair peer-review system, which is all easy to use. Visit http://www.dovepress.com/ testimonials.php to read real quotes from published authors. 